\title{
Alzheimer's disease: synapses gone cold
}

\author{
Robert M Koffie ${ }^{1,2}$, Bradley T Hyman ${ }^{1}$ and Tara L Spires-Jones ${ }^{1 *}$
}

\begin{abstract}
Alzheimer's disease (AD) is a progressive neurodegenerative disease characterized by insidious cognitive decline and memory dysfunction. Synapse loss is the best pathological correlate of cognitive decline in AD and mounting evidence suggests that $A D$ is primarily a disease of synaptic dysfunction. Soluble oligomeric forms of amyloid beta $(A B)$, the peptide that aggregates to form senile plaques in the brain of $A D$ patients, have been shown to be toxic to neuronal synapses both in vitro and in vivo. A $\beta$ oligomers inhibit long-term potentiation (LTP) and facilitate long-term depression (LTD), electrophysiological correlates of memory formation. Furthermore, oligomeric $A \beta$ has also been shown to induce synapse loss and cognitive impairment in animals. The molecular underpinnings of these observations are now being elucidated, and may provide clear therapeutic targets for effectively treating the disease. Here, we review recent findings concerning AD pathogenesis with a particular focus on how A $\beta$ impacts synapses.
\end{abstract}

Keywords: Alzheimer's disease, amyloid-beta, synapse loss, long-term depression, long-term potentiation, cognitive decline

\section{Background}

First described by the German neuropathologist Alois Alzheimer in 1906, Alzheimer's disease (AD) is a progressive neurodegenerative disease characterized by insidious cognitive decline and loss of memory function $[1,2]$. Over 35 million people are afflicted with AD worldwide, 5.5 million of them in the United States alone, and these numbers are expected to quadruple by 2050 [3]. AD is the sixth leading cause of death in the United States, and remains one of the only causes of death that increased by as much as $66 \%$ over the last decade [4]. No disease-modifying drug has been developed for treating $\mathrm{AD}$, making it one of the most pressing public health problems in the world today. Tremendous progress has been made over the last few decades in understanding the underlying biology of the disease. Here we review pertinent research findings concerning $\mathrm{AD}$ pathogenesis with a particular focus on how neuronal synapses are impacted in disease progression. Understanding the molecular underpinnings of AD pathogenesis may aid in developing effective therapeutic approaches for combating it.

\footnotetext{
* Correspondence: tspires@partners.org

${ }^{1}$ Massachusetts General Hospital, Harvard Medical School, 114 16th Street, Charlestown, MA 02129, USA

Full list of author information is available at the end of the article
}

Neuropathology and Pathogenesis of Alzheimer's disease AD is characterized pathologically by cortical atrophy, neuronal cell death, neuroinflammation, synapse loss, and the accumulation of two definitive pathological lesions: neurofibrillary tangles and senile plaques [5]. Neurofibrillary tangles (NFTs) deposit within neurons and are composed of hyperphosphoryated tau protein whereas senile plaques occur in the extracellular space and are made up largely of the 38-43 amino acid peptide amyloid-beta $(A \beta)[6]$. $A \beta$ is believed to be a key trigger of $\mathrm{AD}$ pathogenesis, one that is upstream of NFTs. It is formed by the sequential cleavage of the amyloid precursor protein (APP) by $\beta$ - and $\gamma$-secretase, after which $A \beta$ is released into the extracellular space [6]. There, $A \beta$ can assume a variety of conformational states ranging from monomers to soluble oligomers, protofibrils, and fibrils, which aggregate to form plaques [7-9].

Several lines of evidence support the hypothesis that alterations in amyloid processing can lead to AD. First, APP is located on chromosome 21, and Down syndrome patients who have trisomy of chromosome 21 invariably develop AD [10]. Further, individuals with trisomy 21 with a chromosome 21q break such that APP diploidy occurs in the setting of trisomy 21 do not develop clinical or neuropathological AD [11]. Conversely, a small cohort of patients who inherited an extra copy of APP due to microduplication of small portions of 
chromosome 21q containing the APP locus developed AD-like dementia with plaque deposition [12].

Second, most genetic mutations associated with rare familial early onset $A D$ lead to increased production of $A \beta$ or an increase in $A \beta 42$-to- $A \beta 40$ ratio, which increases the propensity for $A \beta$ aggregation [13]. Mutations leading to early onset familial AD have been found in the APP gene on chromosome 21q [14], in the presenilin 1 gene (PSEN 1) on chromosome 14q, and the presenilin 2 gene (PSEN 2, a homolog of PSEN 1) located on chromosome 1q [13]. Presinilin forms the catalytic site of $\gamma$-secretase, which is one of the enzymes involved in the cleavage of APP to form A [15-17] All of these mutations influence $A \beta$ metabolism and production $[18,19]$.

Third, $\mathrm{A} \beta$ has been shown to be toxic to neurons in vitro and in vivo [6]. Injecting synthetic or naturally secreted $A \beta$, at concentrations akin to those seen in the brains of $\mathrm{AD}$ patients, into the brains of rodents induces behavioral deficits and tau hyperphosphorylation [5].

Fourth, transgenic mouse models overexpressing human APP and/or PSEN genes with known familial early onset $\mathrm{AD}$ mutations develop amyloid plaque deposition and some of the morphological changes of AD (e.g. synapses loss) [20-22]. While most of these transgenic mice do not develop the typical neuronal cell loss observed in $\mathrm{AD}$, they manifest age-dependent memory impairments and cognitive deficits [20-22].

Finally, immunization of $A D$ transgenic mice with $A \beta$ or anti-A $\beta$ antibodies reduces amyloid plaque deposition, clears existing plaques, and ameliorates cognitive deficits in transgenic mice $[23,24]$, indicating that removal of $A \beta$ is beneficial to the brain.

Taken together, these findings suggest that $A \beta$ is an essential element in the pathogenesis of AD. The mechanistic link between $A \beta$ and neurodegeneration, however, remains elusive. Mounting evidence suggests that $\mathrm{AD}$ is primarily a disease of synaptic dysfunction [25] and it is becoming clear that $A \beta$, particularly in oligomeric form, is toxic to synapses. There is therefore a growing interest in understanding how oligomeric $A \beta$ induces synaptic dysfunction in AD.

\section{A $\beta$-mediated synaptic dysfunction in Alzheimer's disease} AD brains are characterized by dramatic synapses loss in mesiotemporal regions [26-29]. Significant synapse loss also occurs in patients with mild cognitive impairment, a harbinger for future $\mathrm{AD}$ [30]. In fact, synapse loss is the best pathological correlate of cognitive dysfunction in $A D$, suggesting that synaptic changes are crucial for AD pathogenesis $[28,31,32]$. Synapse loss is most prominent in the immediate vicinity of senile plaques, suggesting that plaques may be a reservoir of synaptotoxic molecules such as $A \beta$ [33-36]. Indeed, recent studies using multiphoton in vivo imaging revealed a halo of oligomeric $\mathrm{A} \beta$ around plaques in the brain of $\mathrm{AD}$ transgenic mice suggesting that oligomeric $A \beta$ may exist in equilibrium with plaques in $\mathrm{AD}$ [37].

$\mathrm{A} \beta$ oligomerizes via an unknown mechanism, adopting several higher order conformations such as soluble dimers, trimers, dodecamers, higher order oligomers (also named $\mathrm{A} \beta$-derived diffusible ligands (ADDL)), protofibrils, and fibrils [38-42]. Most of these higher order $A \beta$ structures have been found to be toxic to neurons. Synthetic $A \beta$ oligomers or natural soluble oligomeric $A \beta$ purified from the media of cultured cells expressing mutant human APP (hAPP) or extracted directly from the brains of $\mathrm{AD}$ patients have potent synaptic effects. Sodium dodecyl sulfate (SDS) stable A $\beta$ oligomers, ADDLs and protofibrils [43-47] have all been shown to induce synaptic dysfunction [43-48]. Specifically, oligomeric $A \beta$ inhibits the induction of long-term potentiation (LTP), an electrophysiological correlate of memory formation [41,44,49-53]. Biophysical methods such as size exclusion chromatography (SEC) and mass spectroscopy have been used to show that $A \beta$ dimers and trimers are most potent at inhibiting LTP [50,51]. Inhibitors of $A \beta$ oligomerization rescue impairment of LTP induced by $A \beta$ containing media, suggesting that monomeric $A \beta$ is not a potent inhibitor of LTP [54]. Complementing its effects on LTP inhibition, oligomeric $\mathrm{A} \beta$ has also been shown to facilitate the induction of long-term depression (LTD) in hippocampal synapses $[52,55,56]$. Impairments in LTP and facilitation of LTD culminate in synaptic depression and impairments in neuronal networks [57].

\section{Molecular basis of oligomeric $A \beta$ mediated synaptic depression}

The molecular mechanisms underlying oligomeric $A \beta$ mediated synapse dysfunction is very complex. Oligomeric $A \beta$ can induce calcium dyshomeostasis, trigger activation of caspases and calcineurin, and modulate the activity of synaptic excitatory receptors and receptor tyrosine kinases, instigating a cascade of molecular events that culminate in the inhibition of LTP, facilitation of LTD, and synapse loss (Figure 1).

Physiologically, LTP and LTD depend on calcium influx through N-methyl-D-aspartate (NMDA) receptors and/or activation of metabotropic glutamate receptors (mGluRs) [58-62]. Synapse potentiation or depression depends on the rate of influx of calcium as well as the level of cytosolic calcium. LTP occurs when rapid and high levels of calcium influx occur through NMDA receptors, whereas LTD is favored when low level calcium influx through NMDA receptors occurs [63]. LTP requires the activation of NR2A containing NMDA receptors, whereas LTD requires activation of NR2B containing NMDA receptors [64]. These different 


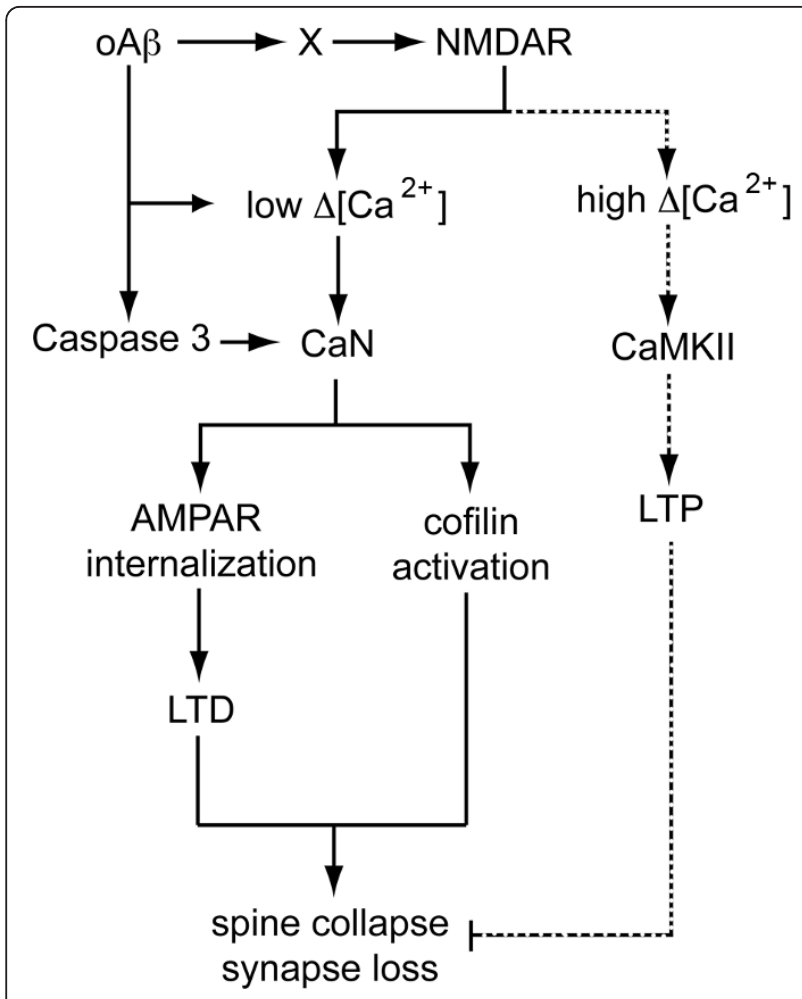

Figure 1 Molecular pathways of oligomeric $A \beta$ mediated synaptic dysfunction. Oligomeric $A \beta$ (OA $\beta$ ) can induce calcium dyshomeostasis, trigger activation of caspase 3 , or modulate the activity of NMDARs either directly or through intermediate molecules (shown as X) involved in the trafficking of NMDAR (e.g. EphB2). Activation of different subtypes of NMDA receptors may trigger different intrasynaptic pathways. Activation of NR2A containing NMDARs may lead to high changes in synaptic calcium concentration $\left(\left[\mathrm{Ca}^{2+}\right]\right)$, which triggers downstream events involving CaMKIl and pCREB (not shown), facilitating the induction of LTP, which promotes dendritic spine enlargement. Alternatively, activation of NR2B containing NMDAR may trigger a low rise in intrasynaptic calcium, which is favored by oA $\beta$ interactions with synapses (away from dotted line pathway), leading to calcineurin (CaN) activation; OA $\beta$-dependent active caspase 3 can also activate CaN. Activated CaN dephosphorylates GluR subunits of AMPARs promoting internalization of AMPARs from the surface of synapses leading to LTD, which leads to dendritic spine shrinkage. Furthermore, active CaN dephosphorylates cofilin rendering it active to depolymerize dendritic spine actin, which leads to dendritic spine collapse and synapse loss.

subclasses of NMDA receptors have distinct calcium influx kinetics $[65,66]$ and modulate distinct postsynaptic signaling pathways $[67,68]$. LTP is associated with dendritic spine enlargement and increase in synapse density, whereas LTD leads to dendritic spine shrinkage and synapse collapse [69-72]. Several protein kinases such as p38 mitogen-activated protein kinase (MAPK), calcium calmodoulin-dependent protein kinase II (CaMKII), glycogen synthase kinase 3-beta (GSK3 $\beta$ ), and ephrin receptor B2 (EphB2) have all been shown to modulate LTP induction in the brain [73,74]. Phosphatases and proteases such as calcineurin (protein phosphatase $2 \mathrm{~B}[\mathrm{PP} 2 \mathrm{~B}]$ ) and caspases play key intracellular roles in the induction of LTD $[58,62,75]$. Transcription factors such as the cyclic AMP response element binding protein (CREB) are crucial for the induction of continuous LTP, by increasing the expression of several genes including those encoding brain derive neurotrophic factor (BDNF) and nitric oxide synthase $[76,77]$.

Oligomeric $A \beta$ has been shown to inhibit LTP and enhance LTD by modulating the activity of all of the above molecular pathways. Oligomeric $A \beta$-induced loss of excitatory synapses in the hippocampus requires functional NMDA receptors [51]. Several studies have shown that oligomeric $A \beta$ induces partial blockade of NMDA receptor currents, which leads to reduction of calcium influx into spines promoting LTD over LTP $[78,79]$. $A \beta$ binds to $7 \alpha$-nicotinic acetylcholine receptors (nAchR) [80], triggering a series of events that leads to internalization of NMDA receptors via a mechanism requiring calcineurin activation [81]. Reduced calcium influx through NMDA receptors induced by $A \beta$ limits CAMKII function, LTP, and spine enlargement [82]. In fact, oligomeric A $\beta$-mediated LTP impairment is believed to involve a decrease in the activation of MAPK, CaMKII and Akt/protein kinase B, but not protein kinases $A$ and $C[53,83,84]$. $A \beta$ has also been shown to induce synaptic depression by activating mGluRs, which triggers a series of downstream molecular events involving MAPK and calcineurin, ultimately promoting internalization of $\alpha$-amino-3-hydroxy-5methyl-4-isoxazolepropionic acid (AMPA) receptors and synapse collapse $[73,85]$. In vivo studies suggest that $A \beta$ indirectly modulates calcineurin activation by causing calcium dysregulation [86-88]. Calcineurin activation promotes the induction of LTD by decreasing surface expression of NMDA receptors and increasing internalization of AMPA receptors via dynamin-mediated endocytosis $[79,89]$. Indeed, $A \beta$-mediated internalization of AMPA [85] and NMDA receptors [81], loss of dendritic spines [85], and cognitive decline [90] can all be rescued by inhibiting calcineurin activation [91-93], indicating that calcineurin plays a crucial role in $\mathrm{A} \beta$-dependent modulation of synaptic plasticity. Further, oligomeric $A \beta$ activation of calcineurin has been shown to induce dendritic simplification, spine loss, and neuritic dystrophies at least in part by activating NFAT (nuclear factor of activated T-cells) pathways both in vitro and in vivo [91]. Oligomeric $A \beta$ has also been shown to activate other synaptic phosphatases such as STEP (striatalenriched tyrosine phosphatase), which function to dephosphorylate NR2B subunits of NMDA receptors and promote their endocytosis, thereby inducing synaptic depression [94-96]. 
Oligomeric $A \beta$ can also directly interact with synaptic surface receptor tyrosine kinases that play key roles in LTP and LTD modulation. For instance, it has been shown that oligomeric $A \beta$ binds to the fibronectin domain of EphB2, a receptor tyrosine kinase known to modulate NMDA receptor trafficking and downstream transcription factors such as Fos, which plays a critical role in the induction of LTP [97-100]. Oligomeric A $\beta$ binding to EphB2 promotes its degradation in the proteasome, impairing the induction of LTP [101]. Indeed, EphB2 is depleted in the brains of transgenic hAPP mice and AD patients [102], and replacement of EphB2 reverses cognitive impairment in hAPP mice [101].

Other studies have shown that $A \beta$ facilitates hippocampal LTD via a mechanism that depends on both NMDAR and mGluR activity. Exogenous extracellular glutamate scavengers reverse oligomeric $A \beta$ mediated facilitation of LTD, whereas inhibitors of glutamate reuptake mimic oligomeric A $\beta$-mediated LTD facilitation, suggesting that the effects of oligomeric $A \beta$ mediated LTD facilitation may occur as a result of impaired glutamate reuptake at the synapse, leading to post-synaptic NMDA receptor desensitization [55]. Metabotropic glutamate receptor activity, GSK-3 $\beta$ signaling, and protein phosphatase $2 \mathrm{~B}$ activity are all necessary for oligomeric-A $\beta$ mediated LTD enhancement [55,73].

Caspase- 3 activity has also been found to be crucial for oligomeric A $\beta$-mediated facilitation of LTD. Soluble $A \beta$ induces caspase- 3 activation at a low level that is not sufficient to induce apoptosis [84]. Mitochondriadependent caspase- 3 activation is necessary for physiologic LTD via a mechanism involving Akt proteolysis [75]. Soluble A $\beta$ activates caspase-3, which leads to LTD via a mechanism involving activation of different protein phosphatases that dephosphorylate AMPA receptors and promote their endocytosis from synaptic surfaces, suggesting that prevention of caspase- 3 activation may be a viable therapeutic approach for treating $\mathrm{AD}$ [84]. Acute inhibition of caspase-3 activity is beneficial, but unfortunately, chronic inhibition of caspase- 3 activation beyond the baseline did not reverse cognitive decline in hAPP mice, but instead exacerbated cognitive impairment, possibly due to a requirement for caspase- 3 activity in normal synaptic function [84]. A $\beta$ also influences CREB activation, which is crucial for the maintenance of LTP, insofar as CREB regulates the expression of genes necessary for LTP. One study showed that $A \beta$ decreases the activity of CREB and thus reduces expression of genes encoding proteins that are essential for LTP [103]. Another study found that excessive activation of extrasynaptic NR2B-containing NMDA receptors, which leads to downregulation of CREB underlies oligomeric $A \beta$ mediated LTP inhibition [104].

\section{Oligomeric $A \beta$ causes synapse shrinkage in Alzheimer's disease}

The acute effects of $A \beta$ on synaptic physiology appear to translate into structural changes in synaptic morphology because enhanced LTD leads to dendritic spine shrinkage whereas inhibition of LTP limits spine enlargement [69-72]. Exposure of cultured neurons or rat hippocampal slices to oligomeric $A \beta$ induces dendritic spine shrinkage and collapse, a phenomenon that can be reversed by treatment with $\mathrm{A} \beta$ antibodies $[51,105]$. APP transgenic mice have significant synapse loss and neutralization of oligomeric $A \beta$ with anti-A $\beta$ antibodies leads to reversal of synapse collapse [106-108]. Furthermore, increased concentration of $A \beta$ may reduce glutamatergic transmission and leads to synapse loss in hAPP transgenic mice even before plaque formation $[21,109,110]$. Oligomeric $A \beta$-mediated inhibition of LTP and enhancement of LTD lead to dendritic spine loss as a result of F-actin remodeling [105]. LTD accompanied by shrinkage of dendritic spines occurs via a mechanism involving cofilinmediated depolymerization of actin [71]. Specifically, $\mathrm{A} \beta$ indirectly stimulates cofilin binding to actin and induction of actin depolymerization in neuronal cytoskeleton. Binding of cofilin to actin is promoted by dephosphorylation at Ser3 by phosphatase Slingshot, and inhibited by phosphorylation by LIM kinase 1 , a process that is modulated by oligomeric A $\beta$ [105]. Indeed, in addition to dendritic spine protein loss, increased amounts of dephosphorylated cofilin have been found in the brain of AD patients [111,112].

\section{Oligomeric $A \beta$ induces cognitive impairments}

The electrochemical and structural effects of oligomeric $\mathrm{A} \beta$ on synapses described above may lead to potent behavioral and cognitive deficits in animals. Intra-cerebral injection of synthetic or naturally secreted oligomeric $A \beta$ impairs complex behavior including memory and cognitive function in animals [113-115]. APP transgenic mice with increased soluble $A \beta$ in the brain display dramatic cognitive impairments even before the onset of plaque deposition [21]. Neutralization of soluble oligomeric $A \beta$ with anti-A $\beta$ antibodies reverses behavioral deficits seen in different AD transgenic mice [116-118], suggesting that behavioral deficits in AD transgenic mice are caused by soluble $A \beta$. Inhibition of oligomeric $A \beta$ formation decreases both histopathological and behavioral AD phenotypes in APP transgenic mice [119], implicating higher order $A \beta$ structures such as soluble oligomeric $A \beta$, but not $A \beta$ monomers, in $A D$ pathogenesis. Levels of soluble oligomeric $A \beta$, but not senile plaques, in the brain correlates with severity of memory loss in human AD patients, however, the precise contribution of different $A \beta$ species to cognitive decline is not clear [120]. 
While it is now well-established that increased oligomeric $A \beta$ levels in the brain leads to synaptic dysfunction, it should be noted that at physiologic levels, $A \beta$ might play a normal role in modulating synaptic activity, which likely becomes deranged in the setting of excess A $\beta$ production or accumulation, leading ultimately to the clinical manifestation of cognitive impairment. Indeed, there is a small but growing body of evidence suggesting that $A \beta$ at low concentrations actually promotes LTP and normal synaptic function [121-124]. Thus, therapeutic approaches aimed at improving cognition by counteracting the toxic effects of $A \beta$ will have to be tailored to target only the toxic function of oligomeric $A \beta$. Nonspecific total inhibition of $A \beta$ may lead to negative effects on synaptic function and cognition.

\section{Seeing $A \beta$ in action at synapses}

Collectively, all of the above evidence suggests that soluble oligomeric $A \beta$ is a potent mediator of cognitive impairment in $\mathrm{AD}$. Oligomeric $\mathrm{A} \beta$ inhibits the induction of LTP, lowers the threshold for inducing LTD, and causes synapse collapse, which may ultimately lead to cognitive decline resulting from disrupted neuronal network connectivity [57]. For several years, limitations in the resolution of conventional microscopy techniques made it difficult to ascertain whether oligomeric $A \beta$ directly associates with neuronal synapses and plays a role in their shrinkage and collapse in vivo. Recent advances in high-resolution microscopy techniques have made it possible to address these questions. For example development of array tomography $[125,126]$, an ultrahigh resolution fluorescence imaging technique that allow direct simultaneous visualization of several thousand small structures such as synapses and peptides in tissue has allowed determination of whether oligomeric A $\beta$ plays a direct role in synapse loss in AD. Using array tomography and a conformation specific antibody
(NAB61) [127], we demonstrated that oligomeric A $\beta$ in the brain of APP/PS1 transgenic mice directly colocalizes with a subset of synapses and is associated with their shrinkage and collapse [37] (Figure 2), suggesting that the in vitro effects of $\mathrm{A} \beta$ oligomers observed using cell based assays likely also occur in vivo, supporting the notion that oligomeric $A \beta$ adversely impacts synapses. High-resolution techniques such as array tomography could be extended to study the effects of oligomeric A $\beta$ on synapses in the brain of AD patients. Furthermore, it will be important to determine whether $A \beta$ oligomers are targeted to synapses by specific carrier proteins or whether they are produced locally at synapses. A number of studies have suggested that production of $A \beta$ (at least in monomeric form) is regulated by activity $[110,128-130]$ and $A \beta$ appears to play a negative feedback function on synaptic activity [110,131,132]. Mechanistically, synaptic activity-dependent production of $A \beta$ requires clathrin-mediated endocytosis of APP, which is then cleaved by $\beta$ - and $\gamma$-secretase in late endosomes at synapses to form A [129]. Nonetheless, it is also possible that $\mathrm{A} \beta$ binding proteins like apolipoprotein $E$, which also play a role at the synapse, may stabilize $A \beta$ oligomers [133] in the extracellular space and deliver them to synaptic sites.

It is presently unclear whether $A \beta$ oligomers interact directly with specific high affinity receptors at the synapse to induce synapse dysfunction. A number of recent studies have reported high affinity binding of oligomeric $\mathrm{A} \beta$ to cellular prion protein $\left(\mathrm{PrP}^{\mathrm{C}}\right)$, which was necessary for $A \beta$ to mediate acute synaptic depression, synapse loss, and cognitive impairment in vivo $[134,135]$. Subsequent studies, however, could not reproduce these findings [136-138]. This is likely because of differences in experimental paradigms used in the subsequent studies. Single particle tracking of A $\beta$ oligomers labeled with quantum dots exposed to hippocampal
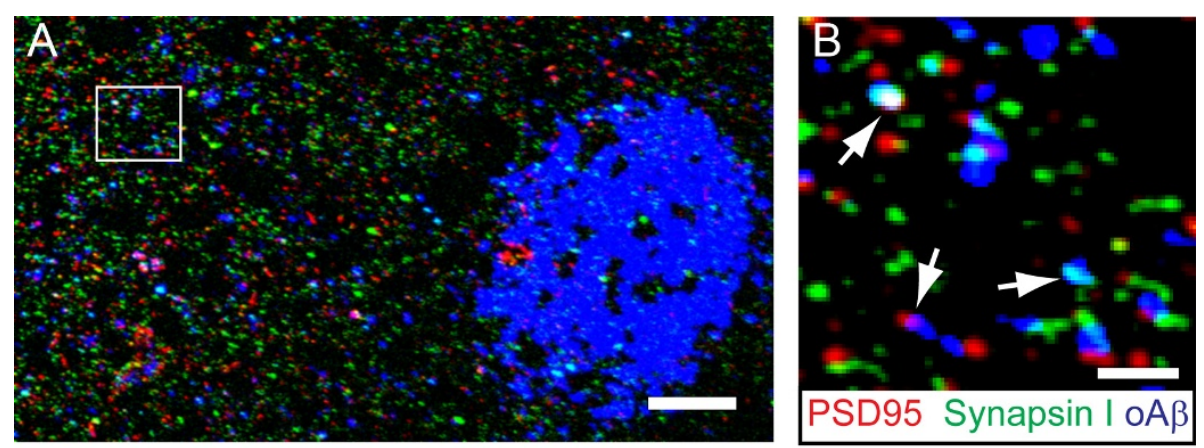

Figure 2 Oligomeric $A \beta$ associates with a subset of synapses in the brain of Alzheimer's disease transgenic mice. A) Array tomograms showing oligomeric $A \beta$ (oA $\beta$ ) localized to synaptic sites near senile plaques in APP/PS1 mice. B) A higher magnification view of the outlined square in panel $\mathbf{A}$ showing multiple pre- and post-synaptic elements colocalized with oA $\beta$ (arrows) stained with an oA $\beta$ specific antibody (NAB61). Scale bar is $10 \mu \mathrm{m}$ in $\mathbf{A}$ and $2 \mu \mathrm{m}$ in $\mathbf{B}$. 
neurons in culture have nonetheless demonstrated that the diffusion of $A \beta$ oligomers is dramatically limited upon binding to synaptic sites, suggesting that high affinity oligomeric $A \beta$ receptors may be present at synapses [139]. Identifying these high affinity receptors could aid in designing drugs capable of blocking the deleterious effects of oligomeric $A \beta$ on neuronal synapses.

\section{Concluding remarks}

Based on the evidence discussed here, we postulate that AD begins as a disease of synaptic dysfunction and synapse loss then progresses to include widespread neuronal loss and neuronal network failure. Findings from recent experiments continue to provide insight into the complicated molecular underpinnings of synapse dysfunction in $\mathrm{AD}$ with mounting evidence pointing to soluble oligomeric $A \beta$ as a key player in the induction of synaptic failure. Oligomeric $A \beta$ activates a variety of molecular cascades that culminate in synapse dysfunction, shrinkage, collapse and loss (Figure 1). These pathological $A \beta$-triggered molecular events, however, may become independent of $A \beta$ as the disease progresses, with downstream tau effects causing overt neuronal loss, exacerbating the loss of connectivity between neurons [140]. If this is correct, at least two main therapeutic approaches could be taken to combat the disease effectively: 1) early interventions that prevent the initiation of $A \beta$-triggered pathological events; or 2) inhibition of specific downstream pathways activated by $A \beta$. The failure of previous therapeutic approaches aimed at removing toxic $A \beta$ species from the brain (e.g. active immunization with $A \beta$ peptide) in clinical trials may be because they were given to the wrong cohort of patients (i.e. patients with advanced $\mathrm{AD}$, whose $\mathrm{A} \beta$-triggered neuronal events may have become independent of $A \beta$ ) [140]. Perhaps, a more effective approach will be to initiate such anti-A $\beta$ therapeutic regimens at very early stages of the disease. For this approach to be successful, highly sensitive and specific biomarkers for diagnosing $\mathrm{AD}$ need to be developed to identify $\mathrm{AD}$ patients at the very early stages of the disease. For patients who have progressed into symptomatic $\mathrm{AD}$, it will likely be necessary to target pathways downstream of $\mathrm{A} \beta$, including tau hyperphosphorylation and accumulation in the soma, which are linked to neuronal death $[141,142]$. In conclusion, $A \beta$-mediated synaptic dysfunction appears to be an important driving factor in $\mathrm{AD}$ pathogenesis and understanding the molecular underpinnings may provide effective therapeutic targets for combating the disease.

\section{Acknowledgements}

This work was supported by K99 AG033670-01A1, Alzheimer's disease Drug Discovery Foundation/Association for Frontotemporal Dementias, P50
AG005134, AG12406, and AG08487. RMK is supported by the Harvard Biophysics and Medical Scientist Training Programs (NIH T32 GM07753) and the Paul and Daisy Soros Foundation.

\section{Author details}

${ }^{1}$ Massachusetts General Hospital, Harvard Medical School, 114 16th Street, Charlestown, MA 02129, USA. ${ }^{2}$ Harvard Biophysics Program, Building C-2, room 122, 240 Longwood Ave, Boston, MA 02115, USA.

\section{Authors' contributions}

RMK designed the layout and content of the review; RMK collected illustrative data, RMK, BTH, and TLS-J wrote the text; all authors read and approved the final manuscript.

\section{Competing interests}

The authors declare that they have no competing interests.

Received: 15 July 2011 Accepted: 26 August 2011

Published: 26 August 2011

\section{References}

1. Alzheimer A: Ubereine eigenartige Erkrankung der Hirnrinde. Allgemeine Zeitschrift fur Psychiatrie und Psychisch-Gerichtliche Medizin 1907, 64:146-148.

2. Goedert M, Spillantini MG: A century of Alzheimer's disease. Science 2006, 314(5800):777-781.

3. Hebert LE, Scherr PA, Bienias JL, Bennett DA, Evans DA: Alzheimer disease in the US population: prevalence estimates using the 2000 census. Arch Neurol 2003, 60(8):1119-1122

4. Alzheimer's A, Thies W, Bleiler L: 2011 Alzheimer's disease facts and figures. Alzheimers Dement 2011, 7(2):208-244.

5. Holtzman DM, Morris JC, Goate AM: Alzheimer's disease: the challenge of the second century. Sci Transl Med 2011, 3(77):77sr71.

6. Hardy J, Selkoe DJ: The amyloid hypothesis of Alzheimer's disease: progress and problems on the road to therapeutics. Science 2002, 297(5580):353-356

7. Kayed R, Head E, Thompson JL, McIntire TM, Milton SC, Cotman CW, Glabe CG: Common structure of soluble amyloid oligomers implies common mechanism of pathogenesis. Science 2003, 300(5618):486-489.

8. Lansbury PT Jr: Evolution of amyloid: what normal protein folding may tell us about fibrillogenesis and disease. Proc Natl Acad Sci USA 1999, 96(7):3342-3344

9. Lansbury PT Jr: In pursuit of the molecular structure of amyloid plaque: new technology provides unexpected and critical information. Biochemistry 1992, 31(30):6865-6870.

10. Tanzi RE, Bertram L: Twenty years of the Alzheimer's disease amyloid hypothesis: a genetic perspective. Cell 2005, 120(4):545-555.

11. Prasher VP, Farrer MJ, Kessling AM, Fisher EM, West RJ, Barber PC, Butler AC: Molecular mapping of Alzheimer-type dementia in Down's syndrome. Ann Neurol 1998, 43(3):380-383.

12. Rovelet-Lecrux A, Hannequin D, Raux G, Le Meur N, Laquerriere A, Vital A, Dumanchin C, Feuillette S, Brice A, Vercelletto M, et al: APP locus duplication causes autosomal dominant early-onset Alzheimer disease with cerebral amyloid angiopathy. Nat Genet 2006, 38(1):24-26.

13. Bertram L, Lill CM, Tanzi RE: The genetics of Alzheimer disease: back to the future. Neuron 2010, 68(2):270-281.

14. Bertram L, Tanzi RE: Thirty years of Alzheimer's disease genetics: the implications of systematic meta-analyses. Nat Rev Neurosci 2008, 9(10):768-778.

15. Osenkowski P, Ye W, Wang R, Wolfe MS, Selkoe DJ: Direct and potent regulation of gamma-secretase by its lipid microenvironment. J Biol Chem 2008, 283(33):22529-22540.

16. Selkoe DJ, Wolfe MS: In search of gamma-secretase: presenilin the cutting edge. Proc Natl Acad Sci USA 2000, 97(11):5690-5692.

17. Wolfe MS, Xia W, Ostaszewski BL, Diehl TS, Kimberly WT, Selkoe DJ: Two transmembrane aspartates in presenilin-1 required for presenilin endoproteolysis and gamma-secretase activity. Nature 1999, 398(6727):513-517.

18. Murakami $K$, Irie $K$, Morimoto A, Ohigashi H, Shindo M, Nagao M, Shimizu T, Shirasawa T: Neurotoxicity and physicochemical properties of Abeta mutant peptides from cerebral amyloid angiopathy: implication for the 
pathogenesis of cerebral amyloid angiopathy and Alzheimer's disease. J Biol Chem 2003, 278(46):46179-46187.

19. Tsubuki S, Takaki Y, Saido TC: Dutch, Flemish, Italian, and Arctic mutations of APP and resistance of Abeta to physiologically relevant proteolytic degradation. Lancet 2003, 361(9373):1957-1958.

20. Games D, Adams D, Alessandrini R, Barbour R, Borthelette P, Blackwell C, Carr T, Clemens J, Donaldson T, Gillespie F, et al: Alzheimer-type neuropathology in transgenic mice overexpressing V717F [beta]-amyloid precursor protein. Nature 1995, 373(6514):523-527.

21. Mucke L, Masliah E, Yu GQ, Mallory M, Rockenstein EM, Tatsuno G, Hu K, Kholodenko D, Johnson-Wood K, McConlogue L: High-level neuronal expression of abeta 1-42 in wild-type human amyloid protein precursor transgenic mice: synaptotoxicity without plaque formation. J Neurosci 2000, 20(11):4050-4058.

22. Lesne S, Koh MT, Kotilinek L, Kayed R, Glabe CG, Yang A, Gallagher M, Ashe KH: A specific amyloid-beta protein assembly in the brain impairs memory. Nature 2006, 440(7082):352-357.

23. Oddo S, Billings L, Kesslak JP, Cribbs DH, LaFerla FM: Abeta immunotherapy leads to clearance of early, but not late, hyperphosphorylated tau aggregates via the proteasome. Neuron 2004, 43(3):321-332.

24. Lemere CA, Masliah E: Can Alzheimer disease be prevented by amyloidbeta immunotherapy? Nat Rev Neurol 2010, 6(2):108-119.

25. Selkoe DJ: Alzheimer's disease is a synaptic failure. Science 2002, 298(5594):789-791

26. Masliah E, Mallory M, Alford M, DeTeresa R, Hansen LA, McKeel DW, Morris JC: Altered expression of synaptic proteins occurs early during progression of Alzheimer's disease. Neurology 2001, 56(1):127-129.

27. DeKosky ST, Scheff SW: Synapse loss in frontal cortex biopsies in Alzheimer's disease: correlation with cognitive severity. Ann Neurol 1990, 27(5):457-464.

28. Terry RD, Masliah E, Salmon DP, Butters N, DeTeresa R, Hill R, Hansen LA, Katzman R: Physical basis of cognitive alterations in Alzheimer's disease: synapse loss is the major correlate of cognitive impairment. Ann Neurol 1991, 30(4):572-580.

29. Davies $C A$, Mann DM, Sumpter $P Q$, Yates PO: A quantitative morphometric analysis of the neuronal and synaptic content of the frontal and temporal cortex in patients with Alzheimer's disease. J Neurol Sci 1987, 78(2):151-164.

30. Scheff SW, Price DA, Schmitt FA, DeKosky ST, Mufson EJ: Synaptic alterations in CA1 in mild Alzheimer disease and mild cognitive impairment. Neurology 2007, 68(18):1501-1508.

31. DeKosky ST, Scheff SW, Styren SD: Structural correlates of cognition in dementia: quantification and assessment of synapse change. Neurodegeneration 1996, 5(4):417-421.

32. Coleman PD, Yao PJ: Synaptic slaughter in Alzheimer's disease. Neurobiol Aging 2003, 24(8):1023-1027.

33. Lanz TA, Carter DB, Merchant KM: Dendritic spine loss in the hippocampus of young PDAPP and Tg2576 mice and its prevention by the ApoE2 genotype. Neurobiol Dis 2003, 13(3):246-253.

34. Moolman DL, Vitolo OV, Vonsattel JP, Shelanski ML: Dendrite and dendritic spine alterations in Alzheimer models. J Neurocytol 2004, 33(3):377-387.

35. Tsai J, Grutzendler J, Duff K, Gan WB: Fibrillar amyloid deposition leads to local synaptic abnormalities and breakage of neuronal branches. Nat Neurosci 2004, 7(11):1181-1183

36. Spires TL, Hannan AJ: Nature, nurture and neurology: gene-environment interactions in neurodegenerative disease. FEBS Anniversary Prize Lecture delivered on 27 June 2004 at the 29th FEBS Congress in Warsaw. FEBS J 2005, 272(10):2347-2361.

37. Koffie RM, Meyer-Luehmann M, Hashimoto T, Adams KW, Mielke ML, GarciaAlloza M, Micheva KD, Smith SJ, Kim ML, Lee VM, et al: Oligomeric amyloid beta associates with postsynaptic densities and correlates with excitatory synapse loss near senile plaques. Proc Natl Acad Sci USA 2009, 106(10):4012-4017.

38. Hartley DM, Walsh DM, Ye CP, Diehl T, Vasquez $\mathrm{S}$, Vassilev PM, Teplow DB, Selkoe DJ: Protofibrillar intermediates of amyloid beta-protein induce acute electrophysiological changes and progressive neurotoxicity in cortical neurons. J Neurosci 1999, 19(20):8876-8884.

39. Walsh DM, Hartley DM, Kusumoto Y, Fezoui Y, Condron MM, Lomakin A, Benedek GB, Selkoe DJ, Teplow DB: Amyloid beta-protein fibrillogenesis.
Structure and biological activity of protofibrillar intermediates. J Biol Chem 1999, 274(36):25945-25952.

40. Harper JD, Wong SS, Lieber CM, Lansbury PT: Observation of metastable Abeta amyloid protofibrils by atomic force microscopy. Chem Biol 1997, 4(2):119-125.

41. Lambert MP, Barlow AK, Chromy BA, Edwards C, Freed R, Liosatos M, Morgan TE, Rozovsky I, Trommer B, Viola KL, et al: Diffusible, nonfibrillar ligands derived from Abeta1-42 are potent central nervous system neurotoxins. Proc Natl Acad Sci USA 1998, 95(11):6448-6453.

42. Lashuel HA, Hartley D, Petre BM, Walz T, Lansbury PT Jr: Neurodegenerative disease: amyloid pores from pathogenic mutations. Nature 2002, 418(6895):291.

43. Walsh DM, Tseng BP, Rydel RE, Podlisny MB, Selkoe DJ: The oligomerization of amyloid beta-protein begins intracellularly in cells derived from human brain. Biochemistry 2000, 39(35):10831-10839.

44. Walsh DM, Klyubin I, Fadeeva JV, Cullen WK, Anwyl R, Wolfe MS, Rowan MJ, Selkoe DJ: Naturally secreted oligomers of amyloid beta protein potently inhibit hippocampal long-term potentiation in vivo. Nature 2002, 416(6880):535-539.

45. Lesné S, Koh MT, Kotilinek L, Kayed R, Glabe CG, Yang A, Gallagher M, Ashe KH: A specific amyloid-[beta] protein assembly in the brain impairs memory. 2006, 440(7082):352-357.

46. Enya M, Morishima-Kawashima M, Yoshimura M, Shinkai Y, Kusui K, Khan K, Games D, Schenk D, Sugihara S, Yamaguchi H, et al: Appearance of sodium dodecyl sulfate-stable amyloid beta-protein (Abeta) dimer in the cortex during aging. Am J Pathol 1999, 154(1):271-279.

47. Funato $H$, Enya $M$, Yoshimura M, Morishima-Kawashima M, Ihara Y: Presence of sodium dodecyl sulfate-stable amyloid beta-protein dimers in the hippocampus CA1 not exhibiting neurofibrillary tangle formation. Am J Pathol 1999, 155(1):23-28.

48. Roher AE, Chaney MO, Kuo YM, Webster SD, Stine WB, Haverkamp LJ, Woods AS, Cotter RJ, Tuohy JM, Krafft GA, et al: Morphology and toxicity of Abeta-(1-42) dimer derived from neuritic and vascular amyloid deposits of Alzheimer's disease. J Biol Chem 1996, 271(34):20631-20635.

49. Wang HW, Pasternak JF, Kuo H, Ristic H, Lambert MP, Chromy B, Viola KL, Klein WL, Stine WB, Krafft GA, et al: Soluble oligomers of beta amyloid (142) inhibit long-term potentiation but not long-term depression in rat dentate gyrus. Brain Res 2002, 924(2):133-140.

50. Townsend M, Shankar GM, Mehta T, Walsh DM, Selkoe DJ: Effects of secreted oligomers of amyloid beta-protein on hippocampal synaptic plasticity: a potent role for trimers. J Physiol 2006, 572(Pt 2):477-492.

51. Shankar GM, Bloodgood BL, Townsend M, Walsh DM, Selkoe DJ, Sabatini BL: Natural oligomers of the Alzheimer amyloid-beta protein induce reversible synapse loss by modulating an NMDA-type glutamate receptor-dependent signaling pathway. J Neurosci 2007, 27(11):2866-2875.

52. Shankar GM, Li S, Mehta TH, Garcia-Munoz A, Shepardson NE, Smith I, Brett FM, Farrell MA, Rowan MJ, Lemere CA, et al: Amyloid-beta protein dimers isolated directly from Alzheimer's brains impair synaptic plasticity and memory. Nat Med 2008, 14(8):837-842.

53. Townsend M, Mehta T, Selkoe DJ: Soluble Abeta inhibits specific signal transduction cascades common to the insulin receptor pathway. $J$ Biol Chem 2007, 282(46):33305-33312.

54. Walsh DM, Townsend M, Podlisny MB, Shankar GM, Fadeeva JV, El Agnaf O, Hartley DM, Selkoe DJ: Certain inhibitors of synthetic amyloid betapeptide (Abeta) fibrillogenesis block oligomerization of natural Abeta and thereby rescue long-term potentiation. J Neurosci 2005, 25(10):2455-2462.

55. Li S, Hong S, Shepardson NE, Walsh DM, Shankar GM, Selkoe D: Soluble oligomers of amyloid Beta protein facilitate hippocampal long-term depression by disrupting neuronal glutamate uptake. Neuron 2009, 62(6):788-801.

56. Kim JH, Anwyl R, Suh YH, Djamgoz MB, Rowan MJ: Use-dependent effects of amyloidogenic fragments of (beta)-amyloid precursor protein on synaptic plasticity in rat hippocampus in vivo. J Neurosci 2001, 21(4):1327-1333

57. Palop JJ, Mucke L: Amyloid-beta-induced neuronal dysfunction in Alzheimer's disease: from synapses toward neural networks. Nat Neurosci 2010, 13(7):812-818.

58. Kemp N, Bashir Zl: Long-term depression: a cascade of induction and expression mechanisms. Prog Neurobiol 2001, 65(4):339-365. 
59. Wu J, Rowan MJ, Anwyl R: Long-term potentiation is mediated by multiple kinase cascades involving CaMKII or either PKA or p42/44 MAPK in the adult rat dentate gyrus in vitro. J Neurophysiol 2006, 95(6):3519-3527

60. Harney SC, Rowan M, Anwyl R: Long-term depression of NMDA receptormediated synaptic transmission is dependent on activation of metabotropic glutamate receptors and is altered to long-term potentiation by low intracellular calcium buffering. J Neurosci 2006, 26(4):1128-1132

61. Anwyl R: Induction and expression mechanisms of postsynaptic NMDA receptor-independent homosynaptic long-term depression. Prog Neurobiol 2006, 78(1):17-37

62. Citri A, Malenka RC: Synaptic plasticity: multiple forms, functions, and mechanisms. Neuropsychopharmacology 2008, 33(1):18-41.

63. Kullmann DM, Lamsa KP: Long-term synaptic plasticity in hippocampal interneurons. Nat Rev Neurosci 2007, 8(9):687-699.

64. Liu L, Wong TP, Pozza MF, Lingenhoehl K, Wang Y, Sheng M, Auberson YP, Wang YT: Role of NMDA receptor subtypes in governing the direction of hippocampal synaptic plasticity. Science 2004, 304(5673):1021-1024.

65. Sheng M, Cummings J, Roldan LA, Jan YN, Jan LY: Changing subunit composition of heteromeric NMDA receptors during development of rat cortex. Nature 1994, 368(6467):144-147.

66. Chen N, Luo T, Raymond LA: Subtype-dependence of NMDA receptor channel open probability. J Neurosci 1999, 19(16):6844-6854.

67. Sprengel R, Suchanek B, Amico C, Brusa R, Burnashev N, Rozov A, Hvalby O, Jensen $V$, Paulsen $O$, Andersen $P$, et al: Importance of the intracellular domain of NR2 subunits for NMDA receptor function in vivo. Cell 1998, 92(2):279-289.

68. Sheng M, Pak DT: Ligand-gated ion channel interactions with cytoskeletal and signaling proteins. Annu Rev Physiol 2000, 62:755-778.

69. Matsuzaki M, Honkura N, Ellis-Davies GC, Kasai H: Structural basis of longterm potentiation in single dendritic spines. Nature 2004, 429(6993):761-766.

70. Nagerl UV, Eberhorn N, Cambridge SB, Bonhoeffer T: Bidirectional activitydependent morphological plasticity in hippocampal neurons. Neuron 2004, 44(5):759-767.

71. Zhou Q, Homma KJ, Poo MM: Shrinkage of dendritic spines associated with long-term depression of hippocampal synapses. Neuron 2004, 44(5):749-757.

72. Bastrikova N, Gardner GA, Reece JM, Jeromin A, Dudek SM: Synapse elimination accompanies functional plasticity in hippocampal neurons. Proc Natl Acad Sci USA 2008, 105(8):3123-3127.

73. Wang Q, Walsh DM, Rowan MJ, Selkoe DJ, Anwyl R: Block of long-term potentiation by naturally secreted and synthetic amyloid beta-peptide in hippocampal slices is mediated via activation of the kinases c-Jun $\mathrm{N}$ terminal kinase, cyclin-dependent kinase 5, and p38 mitogen-activated protein kinase as well as metabotropic glutamate receptor type 5. J Neurosci 2004, 24(13):3370-3378.

74. Tackenberg C, Brandt R: Divergent pathways mediate spine alterations and cell death induced by amyloid-beta, wild-type tau, and R406W tau. J Neurosci 2009, 29(46):14439-14450.

75. Li Z, Jo J, Jia JM, Lo SC, Whitcomb DJ, Jiao S, Cho K, Sheng M: Caspase-3 activation via mitochondria is required for long-term depression and AMPA receptor internalization. Cell 2010, 141(5):859-871.

76. Mayr BM, Canettieri G, Montminy MR: Distinct effects of cAMP and mitogenic signals on CREB-binding protein recruitment impart specificity to target gene activation via CREB. Proc Natl Acad Sci USA 2001, 98(19):10936-10941.

77. Mayr B, Montminy M: Transcriptional regulation by the phosphorylationdependent factor CREB. Nat Rev Mol Cell Biol 2001, 2(8):599-609.

78. Cummings BJ, Pike CJ, Shankle R, Cotman CW: Beta-amyloid deposition and other measures of neuropathology predict cognitive status in Alzheimer's disease. Neurobiol Aging 1996, 17(6):921-933.

79. Mulkey RM, Endo S, Shenolikar S, Malenka RC: Involvement of a calcineurin/inhibitor-1 phosphatase cascade in hippocampal long-term depression. Nature 1994, 369(6480):486-488.

80. Wang HY, Lee DH, D'Andrea MR, Peterson PA, Shank RP, Reitz AB: betaAmyloid(1-42) binds to alpha7 nicotinic acetylcholine receptor with high affinity. Implications for Alzheimer's disease pathology. J Biol Chem 2000, 275(8):5626-5632.
81. Snyder EM, Nong Y, Almeida CG, Paul S, Moran T, Choi EY, Nairn AC, Salter MW, Lombroso PJ, Gouras GK, et al: Regulation of NMDA receptor trafficking by amyloid-beta. Nat Neurosci 2005, 8(8):1051-1058.

82. Nicoll RA, Malenka RC: Expression mechanisms underlying NMDA receptor-dependent long-term potentiation. Ann N Y Acad Sci 1999 868:515-525.

83. Jo J, Whitcomb DJ, Olsen KM, Kerrigan TL, Lo SC, Bru-Mercier G, Dickinson B, Scullion S, Sheng M, Collingridge $G$, et al: Abeta(1-42) inhibition of LTP is mediated by a signaling pathway involving caspase3, Akt1 and GSK-3beta. Nat Neurosci 2011, 14(5):545-547.

84. D'Amelio M, Cavallucci V, Middei S, Marchetti C, Pacioni S, Ferri A, Diamantini A, De Zio D, Carrara P, Battistini L, et al: Caspase-3 triggers early synaptic dysfunction in a mouse model of Alzheimer's disease. Nat Neurosci 2011, 14(1):69-76.

85. Hsieh H, Boehm J, Sato C, Iwatsubo T, Tomita T, Sisodia S, Malinow R: AMPAR removal underlies Abeta-induced synaptic depression and dendritic spine loss. Neuron 2006, 52(5):831-843.

86. Abdul HM, Sama MA, Furman JL, Mathis DM, Beckett TL, Weidner AM, Patel ES, Baig I, Murphy MP, LeVine $H$, et al: Cognitive decline in Alzheimer's disease is associated with selective changes in calcineurin/ NFAT signaling. J Neurosci 2009, 29(41):12957-12969.

87. Kuchibhotla KV, Goldman ST, Lattarulo CR, Wu HY, Hyman BT, Bacskai BJ: Abeta plaques lead to aberrant regulation of calcium homeostasis in vivo resulting in structural and functional disruption of neuronal networks. Neuron 2008, 59(2):214-225

88. Wen Z, Guirland C, Ming GL, Zheng JQ: A CaMKII/calcineurin switch controls the direction of $\mathrm{Ca}(2+)$-dependent growth cone guidance. Neuron 2004, 43(6):835-846.

89. Slepnev VI, Ochoa GC, Butler MH, Grabs D, De Camilli P: Role of phosphorylation in regulation of the assembly of endocytic coat complexes. Science 1998, 281(5378):821-824.

90. Dineley KT, Hogan D, Zhang WR, Taglialatela G: Acute inhibition of calcineurin restores associative learning and memory in Tg2576 APP transgenic mice. Neurobiol Learn Mem 2007, 88(2):217-224.

91. Wu HY, Hudry E, Hashimoto T, Kuchibhotla K, Rozkalne A, Fan Z, SpiresJones $\mathrm{T}$, Xie H, Arbel-Ornath M, Grosskreutz CL, et al: Amyloid beta induces the morphological neurodegenerative triad of spine loss, dendritic simplification, and neuritic dystrophies through calcineurin activation. J Neurosci 2010, 30(7):2636-2649.

92. Rozkalne A, Hyman BT, Spires-Jones TL: Calcineurin inhibition with FK506 ameliorates dendritic spine density deficits in plaque-bearing Alzheimer model mice. Neurobiol Dis 2011, 41(3):650-654.

93. Spires-Jones TL, Kay K, Matsouka R, Rozkalne A, Betensky RA, Hyman BT: Calcineurin inhibition with systemic FK506 treatment increases dendritic branching and dendritic spine density in healthy adult mouse brain. Neurosci Lett 2011, 487(3):260-263.

94. Zhang Y, Kurup P, Xu J, Carty N, Fernandez SM, Nygaard HB, Pittenger C, Greengard P, Strittmatter SM, Nairn AC, et al: Genetic reduction of striatalenriched tyrosine phosphatase (STEP) reverses cognitive and cellular deficits in an Alzheimer's disease mouse model. Proc Natl Acad Sci USA 2010, 107(44):19014-19019.

95. Kurup P, Zhang Y, Venkitaramani DV, Xu J, Lombroso PJ: The role of STEP in Alzheimer's disease. Channels (Austin) 2010, 4(5):347-350.

96. Kurup P, Zhang Y, Xu J, Venkitaramani DV, Haroutunian V, Greengard P, Nairn AC, Lombroso PJ: Abeta-mediated NMDA receptor endocytosis in Alzheimer's disease involves ubiquitination of the tyrosine phosphatase STEP61. J Neurosci 2010, 30(17):5948-5957.

97. Takasu MA, Dalva MB, Zigmond RE, Greenberg ME: Modulation of NMDA receptor-dependent calcium influx and gene expression through EphB receptors. Science 2002, 295(5554):491-495.

98. Henderson JT, Georgiou J, Jia Z, Robertson J, Elowe S, Roder JC, Pawson T: The receptor tyrosine kinase EphB2 regulates NMDA-dependent synaptic function. Neuron 2001, 32(6):1041-1056.

99. Dalva MB, Takasu MA, Lin MZ, Shamah SM, Hu L, Gale NW, Greenberg ME: EphB receptors interact with NMDA receptors and regulate excitatory synapse formation. Cell 2000, 103(6):945-956.

100. Chen Y, Fu AK, Ip NY: Bidirectional signaling of ErbB and Eph receptors at synapses. Neuron Glia Biol 2008, 4(3):211-221.

101. Cisse M, Halabisky B, Harris J, Devidze N, Dubal DB, Sun B, Orr A, Lotz G, Kim DH, Hamto $P$, et al: Reversing EphB2 depletion rescues cognitive functions in Alzheimer model. Nature 2011, 469(7328):47-52. 
102. Simon AM, de Maturana RL, Ricobaraza A, Escribano L, Schiapparelli L, Cuadrado-Tejedor M, Perez-Mediavilla A, Avila J, Del Rio J, Frechilla D: Early changes in hippocampal Eph receptors precede the onset of memory decline in mouse models of Alzheimer's disease. J Alzheimers Dis 2009, 17(4):773-786.

103. Vitolo OV, Sant'Angelo A, Costanzo V, Battaglia F, Arancio O, Shelanski M: Amyloid beta -peptide inhibition of the PKA/CREB pathway and longterm potentiation: reversibility by drugs that enhance CAMP signaling. Proc Natl Acad Sci USA 2002, 99(20):13217-13221.

104. Li S, Jin M, Koeglsperger T, Shepardson NE, Shankar GM, Selkoe DJ: Soluble A\{beta\} Oligomers Inhibit Long-Term Potentiation through a Mechanism Involving Excessive Activation of Extrasynaptic NR2B-Containing NMDA Receptors. J Neurosci 2011, 31(18):6627-6638.

105. Selkoe DJ: Soluble oligomers of the amyloid beta-protein impair synaptic plasticity and behavior. Behav Brain Res 2008, 192(1):106-113.

106. Spires TL, Meyer-Luehmann M, Stern EA, McLean PJ, Skoch J, Nguyen PT, Bacskai BJ, Hyman BT: Dendritic spine abnormalities in amyloid precursor protein transgenic mice demonstrated by gene transfer and intravital multiphoton microscopy. J Neurosci 2005, 25(31):7278-7287.

107. Rozkalne A, Spires-Jones TL, Stern EA, Hyman BT: A single dose of passive immunotherapy has extended benefits on synapses and neurites in an Alzheimer's disease mouse model. Brain Res 2009, 1280:178-185.

108. Spires-Jones TL, Mielke ML, Rozkalne A, Meyer-Luehmann M, de Calignon A, Bacskai BJ, Schenk D, Hyman BT: Passive immunotherapy rapidly increases structural plasticity in a mouse model of Alzheimer disease. Neurobiol Dis 2009, 33(2):213-220.

109. Hsia AY, Masliah E, McConlogue L, Yu GQ, Tatsuno G, Hu K, Kholodenko D, Malenka RC, Nicoll RA, Mucke L: Plaque-independent disruption of neural circuits in Alzheimer's disease mouse models. Proc Natl Acad Sci USA 1999, 96(6):3228-3233.

110. Kamenetz F, Tomita T, Hsieh H, Seabrook G, Borchelt D, Iwatsubo T, Sisodia S, Malinow R: APP processing and synaptic function. Neuron 2003, 37(6):925-937.

111. Ferrer I, Gullotta F: Down's syndrome and Alzheimer's disease: dendritic spine counts in the hippocampus. Acta Neuropathol 1990, 79(6):680-685.

112. Minamide LS, Striegl AM, Boyle JA, Meberg PJ, Bamburg JR: Neurodegenerative stimuli induce persistent ADF/cofilin-actin rods that disrupt distal neurite function. Nat Cell Biol 2000, 2(9):628-636.

113. O'Hare E, Weldon DT, Mantyh PW, Ghilardi JR, Finke MP, Kuskowski MA, Maggio JE, Shephard RA, Cleary J: Delayed behavioral effects following intrahippocampal injection of aggregated A beta (1-42). Brain Res 1999, 815(1):1-10.

114. Cleary JP, Walsh DM, Hofmeister JJ, Shankar GM, Kuskowski MA, Selkoe DJ, Ashe $\mathrm{KH}$ : Natural oligomers of the amyloid-beta protein specifically disrupt cognitive function. Nat Neurosci 2005, 8(1):79-84.

115. Cleary J, Hittner JM, Semotuk M, Mantyh P, O'Hare E: Beta-amyloid(1-40) effects on behavior and memory. Brain Res 1995, 682(1-2):69-74

116. Kotilinek LA, Bacskai B, Westerman M, Kawarabayashi T, Younkin L, Hyman BT, Younkin S, Ashe KH: Reversible memory loss in a mouse transgenic model of Alzheimer's disease. J Neurosci 2002, 22(15):6331-6335.

117. Dodart JC, Bales KR, Gannon KS, Greene SJ, DeMattos RB, Mathis C, Delong CA, Wu S, Wu X, Holtzman DM, et al: Immunization reverses memory deficits without reducing brain Abeta burden in Alzheimer's disease model. Nat Neurosci 2002, 5(5):452-457.

118. Klyubin I, Walsh DM, Lemere CA, Cullen WK, Shankar GM, Betts V, Spooner ET, Jiang L, Anwyl R, Selkoe DJ, et al: Amyloid beta protein immunotherapy neutralizes Abeta oligomers that disrupt synaptic plasticity in vivo. Nat Med 2005, 11(5):556-561.

119. McLaurin J, Kierstead ME, Brown ME, Hawkes CA, Lambermon MH, Phinney AL, Darabie AA, Cousins JE, French JE, Lan MF, et al: Cyclohexanehexol inhibitors of Abeta aggregation prevent and reverse Alzheimer phenotype in a mouse model. Nat Med 2006, 12(7):801-808.

120. Gong Y, Chang L, Viola KL, Lacor PN, Lambert MP, Finch CE, Krafft GA, Klein WL: Alzheimer's disease-affected brain: presence of oligomeric A beta ligands (ADDLs) suggests a molecular basis for reversible memory loss. Proc Natl Acad Sci USA 2003, 100(18):10417-10422.

121. Puzzo D, Privitera L, Fa M, Staniszewski A, Hashimoto G, Aziz F, Sakurai M, Ribe EM, Troy CM, Mercken M, et al: Endogenous amyloid-beta is necessary for hippocampal synaptic plasticity and memory. Ann Neurol 2011, 69(5):819-830.
122. Puzzo D, Privitera L, Leznik E, Fa M, Staniszewski A, Palmeri A, Arancio O: Picomolar Amyloid-\{beta\} Positively Modulates Synaptic Plasticity and Memory in Hippocampus. 10.1523/JNEUROSCI.2692-08.2008. J Neurosci 2008, 28(53):14537-14545.

123. Venkitaramani DV, Chin J, Netzer WJ, Gouras GK, Lesne S, Malinow R, Lombroso PJ: Beta-amyloid modulation of synaptic transmission and plasticity. J Neurosci 2007, 27(44):11832-11837.

124. Abramov E, Dolev I, Fogel H, Ciccotosto GD, Ruff E, Slutsky I: Amyloid-beta as a positive endogenous regulator of release probability at hippocampal synapses. Nat Neurosci 2009, 12(12):1567-1576.

125. Micheva KD, O'Rourke N, Busse B, Smith SJ: Array tomography: production of arrays. Cold Spring Harb Protoc 2010, 2010(11), pdb prot 5524.

126. Micheva KD, Smith SJ: Array tomography: a new tool for imaging the molecular architecture and ultrastructure of neural circuits. Neuron 2007, 55(1):25-36.

127. Lee EB, Leng LZ, Zhang B, Kwong L, Trojanowski JQ, Abel T, Lee VM: Targeting amyloid-beta peptide (Abeta) oligomers by passive immunization with a conformation-selective monoclonal antibody improves learning and memory in Abeta precursor protein (APP) transgenic mice. J Biol Chem 2006, 281(7):4292-4299.

128. Cirrito JR, Yamada KA, Finn MB, Sloviter RS, Bales KR, May PC, Schoepp DD, Paul SM, Mennerick S, Holtzman DM: Synaptic activity regulates interstitial fluid amyloid-beta levels in vivo. Neuron 2005, 48(6):913-922.

129. Cirrito JR, Kang JE, Lee J, Stewart FR, Verges DK, Silverio LM, Bu G, Mennerick S, Holtzman DM: Endocytosis is required for synaptic activitydependent release of amyloid-beta in vivo. Neuron 2008, 58(1):42-51.

130. Cirrito JR, May PC, O'Dell MA, Taylor JW, Parsadanian M, Cramer JW Audia JE, Nissen JS, Bales KR, Paul SM, et al: In vivo assessment of brain interstitial fluid with microdialysis reveals plaque-associated changes in amyloid-beta metabolism and half-life. J Neurosci 2003, 23(26):8844-8853.

131. Ting JT, Kelley BG, Lambert TJ, Cook DG, Sullivan JM: Amyloid precursor protein overexpression depresses excitatory transmission through both presynaptic and postsynaptic mechanisms. Proc Natl Acad Sci USA 2007, 104(1):353-358.

132. Priller C, Bauer T, Mitteregger G, Krebs B, Kretzschmar HA, Herms J: Synapse formation and function is modulated by the amyloid precursor protein. J Neurosci 2006, 26(27):7212-7221

133. Cerf E, Gustot A, Goormaghtigh E, Ruysschaert JM, Raussens V: High ability of apolipoprotein E4 to stabilize amyloid-\{beta\} peptide oligomers, the pathological entities responsible for Alzheimer's disease. FASEB J 2011, 25(5):1585-1595

134. Lauren J, Gimbel DA, Nygaard HB, Gilbert JW, Strittmatter SM: Cellular prion protein mediates impairment of synaptic plasticity by amyloidbeta oligomers. Nature 2009, 457(7233):1128-1132

135. Barry AE, Klyubin I, Mc Donald JM, Mably AJ, Farrell MA, Scott M, Walsh DM, Rowan MJ: Alzheimer's Disease Brain-Derived Amyloid-\{beta\}-Mediated Inhibition of LTP In Vivo Is Prevented by Immunotargeting Cellular Prion Protein. J Neurosci 2011, 31(20):7259-7263.

136. Kessels HW, Nguyen LN, Nabavi S, Malinow R: The prion protein as a receptor for amyloid-beta. Nature 2010, 466(7308):E3-4; discussion E4-5.

137. Balducci C, Beeg M, Stravalaci M, Bastone A, Sclip A, Biasini E, Tapella L, Colombo L, Manzoni C, Borsello T, et al: Synthetic amyloid-beta oligomers impair long-term memory independently of cellular prion protein. Proc Natl Acad Sci USA 2010, 107(5):2295-2300.

138. Calella AM, Farinelli M, Nuvolone M, Mirante O, Moos R, Falsig J, Mansuy IM, Aguzzi A: Prion protein and Abeta-related synaptic toxicity impairment. EMBO Mol Med 2010, 2(8):306-314.

139. Renner M, Lacor PN, Velasco PT, Xu J, Contractor A, Klein WL, Triller A: Deleterious effects of amyloid beta oligomers acting as an extracellular scaffold for mGluR5. Neuron 2010, 66(5):739-754.

140. Hyman BT: Amyloid-Dependent and Amyloid-Independent Stages of Alzheimer Disease. Arch Neurol 2011.

141. Spires-Jones TL, Kopeikina KJ, Koffie RM, de Calignon A, Hyman BT: Are Tangles as Toxic as They Look? J Mol Neurosci 2011.

142. Spires-Jones TL, de Calignon A, Meyer-Luehmann M, Bacskai BJ, Hyman BT: Monitoring protein aggregation and toxicity in Alzheimer's disease mouse models using in vivo imaging. Methods 2011, 53(3):201-207.

doi:10.1186/1750-1326-6-63

Cite this article as: Koffie et al:: Alzheimer's disease: synapses gone cold.

Molecular Neurodegeneration 2011 6:63. 